\title{
The Activation of Plasminogen by Hageman Factor (Factor XII) and Hageman Factor Fragments
}

\author{
George H. Goldsmith, JR., Hidehiko Saito, and Oscar D. Ratnoff, \\ Department of Medicine, School of Medicine, Case Western Reserve University \\ and University Hospitals of Cleveland, Cleveland, Ohio 44106
}

\begin{abstract}
A B S T R A C T Activation of plasminogen through surface-mediated reactions is well recognized. In the presence of kaolin, purified Hageman factor (Factor XII) changed plasminogen to plasmin, as assayed upon a synthetic amide substrate and by fibrinolysis. Kinetic studies suggested an enzymatic action of Hageman factor upon its substrate, plasminogen. Hageman factor fragments, at a protein concentration equivalent to whole Hageman factor, activated plasminogen to a lesser extent. These protein preparations were not contaminated with other agents implicated in surfacemediated fibrinolysis. Diisopropyl fluorophosphate treatment of plasminogen did not inhibit its activation by Hageman factor. These studies indicate that Hageman factor has a hitherto unsuspected function, the direct activation of plasminogen.
\end{abstract}

\section{INTRODUCTION}

Plasminogen, a normal constituent of human plasma, may be converted to the fibrinolytic enzyme, plasmin, in many ways. Activators derived from sources extrinsic to the circulation or from circulating blood cells (1) have been described. Activation of plasminogen can also occur through surface-mediated pathways involving only factors endogenous to human plasma. Studies of congenitally deficient plasmas indicate the participation of Hageman factor $\left(\mathrm{HF},{ }^{1}\right.$ Factor XII), prekallikrein, and high molecular weight kininogen (HMWK, Fitz-

Dr. Goldsmith is a Career Investigator Fellow of the American Heart Association. Dr. Ratnoff is a Career Investigator of the American Heart Association.

Address reprint requests to Dr. Goldsmith.

Received for publication 25 August 1977 and in revised form 26 January 1978.

${ }^{1}$ Abbreviations used in this paper: CTA, Committee on Thrombolytic Agents; DFP, diisopropyl fluorophosphate; HF, Hageman factor; $\mathrm{HF}_{\mathrm{f}}$, Hageman Factor fragments; HMWK, high molecular weight kininogen; pNA, p-nitroaniline; pTA, plasma thromboplastin antecedent; PPAN, benzoyl-prolylphenylalanyl-argine-p-nitroanilide; VLLN, H-D-valyl-leucyllysine- $p$-nitroanilide $\cdot 2$ HCL. gerald factor) in surface-mediated fibrinolysis (2-7). The number and order of action of these proteins in fibrinolysis have not been completely elucidated. Colman (8) reported that purified plasma kallikrein directly activates plasminogen to plasmin. Other substances originally identified as HF-cofactor (9), plasminogen proactivator (10), and plasma thromboplastin antecedent (PTA, Factor XI) (11) have also been proposed as separate activators of plasminogen, but they have not been fully characterized. In a common construct, activated HF converts another zymogen to an enzymatic form which then activates plasminogen (12).

To clarify the role of HF in this system, we studied the interaction of purified human plasminogen with purified HF and its small molecular weight $(30,000)$ fragment released by insoluble trypsin. These agents appeared to activate plasminogen without the participation of other agents.

\section{METHODS}

Oxalated and citrated normal and factor-deficient plasmas, for use in coagulation assays and as a source of purified proteins, were collected as described (13).

Lysine-Sepharose 4B was prepared from CNBr-activated Sepharose 4B (14) (Pharmacia Fine Chemicals, Piscataway, N. J.) according to instructions by the manufacturers. For both plasminogen purification and depletion of plasminogen in $\mathrm{HF}$ preparations, the lysine-Sepharose $4 \mathrm{~B}$ was equilibrated with a solution of $0.1 \mathrm{M}$ sodium phosphate buffer ( $\mathrm{pH} 7.5$ ), containing $0.1 \mathrm{mM}$ sodium EDTA, and $50 \mathrm{mg} / \mathrm{liter}$ hexadimethrine bromide (Polybrene, Aldrich Chemical Co., Inc., Milwaukee, Wis.).

Human HF (Factor XII) was prepared by a modification of published methods (4). The $\mathrm{HF}$ fraction of tricalcium phosphate-adsorbed oxalated plasma was adsorbed to and eluted from QAE Sephadex A-50 (Pharmacia Fine Chemicals) in a batch procedure. After concentration with ammonium sulfate and dialysis, successive adsorption to gradient elution from DEAE Sephadex A-50 and SP Sephadex C-50 (Pharmacia Fine chemicals) was performed, followed by gel filtration upon columns of Sephadex G-150 (Pharmacia Fine Chemicals).

This sequence was modified to insure depletion of 
plasminogen. Two techniques were used. A $250-\mathrm{ml}$ volume of oxalated plasma that had been adsorbed with tricalcium phosphate was immediately filtered through two successive columns of lysine-Sepharose $4 \mathrm{~B}(2.5 \times 40 \mathrm{~cm})$, equilibrated with $0.1 \mathrm{M}$ sodium phosphate buffer $(\mathrm{pH} \mathrm{8.0)}$, and then dialyzed against the QAE buffer, after which purification was continued in the manner described. Alternatively, the QAE Sephadex fractions of plasma (see above), after ammonium sulfate concentration and exhaustive dialysis against the phosphate buffer, were filtered through lysine-Sepharose equilibrated with the same buffer (one or more $2.5 \times 20-\mathrm{cm}$ columns $/ 500 \mathrm{ml}$ starting plasma, depending upon the completeness of plasminogen removal, as determined by assay). The lysine-Sepharose effluents were then dialyzed against the DEAE buffer and purification completed as described (4). All buffer solutions throughout the purification procedure were modified by the addition of benzamidine $\mathrm{HCl}, 5 \mathrm{mM}$ to $100 \mathrm{mM}$, with the exception of the barbital-saline buffer (13) against which the final product was dialyzed, and stored at $-70^{\circ} \mathrm{C}$ in silicone-coated polyethylene vials. HF purified in this fashion had a sp act of $52-77 \mathrm{U} / \mathrm{mg}, 1 \mathrm{U}$ being the amount present in $1 \mathrm{ml}$ of normal pooled plasma (13).

$\mathrm{HF}$ fragments $\left(\mathrm{HF}_{\mathrm{f}}\right)$ were prepared by treatment of purified human $\mathrm{HF}$ with rehydrated Enzite-trypsin (Miles Laboratories, Inc., Miles Research Products, Elkhart, Ind.). $\mathrm{HF}$ and Enzite-trypsin (1 $\mathrm{mg} / \mathrm{U} \mathrm{HF}$ ) were incubated at $37^{\circ} \mathrm{C}$ for $30 \mathrm{~min}$, followed by centrifugation at $2,700 \mathrm{~g}$ for 5 min at $2^{\circ} \mathrm{C}$. The supernatant fluid was then filtered through a column of Sephadex G-150 $(1.5 \times 90 \mathrm{~cm})$ equilibrated with barbital-saline buffer. The peak of $\mathrm{HF}_{\mathrm{f}}$, estimated as plasma prekallikrein-activating activity, was determined by amidolysis of benzoyl-prolyl-phenylalanyl-arginine- $p$ nitroanilide (PPAN) $\cdot$ HCl (Pentapharm Ltd, Basel Switzerland), using the assay described below. Fractions with peak activity were pooled, concentrated by ultrafiltration (Amicon Corp. Scientific Sys., Lexington, Mass.) under positive pressure using a PM-10 membrane (Diaflo, Amicon Corp.) and stored at $-70^{\circ} \mathrm{C}$ in silicone-coated polyethylene vials. The $\mathrm{HF}_{\mathrm{f}}$ were present in fractions corresponding in molecular weight to $\cong 30,000$, as determined by comparison to soybean trypsin inhibitor (Worthington Biochemical Corp., Freehold, N. J.) and bovine serum albumin (Miles Laboratories Inc., Kankakee, Ill.) filtered over the same column.

Human plasminogen was prepared by the method of Deutsch and Mertz (14), with the following modifications. Venous blood was drawn into $250 \mathrm{ml}$ polypropylene vials containing $5 \mathrm{ml}$ of $0.5 \mathrm{M}$ disodium citrate buffer (pH 5.0) with $9.5 \mathrm{mg}$ EDTA, $12.5 \mathrm{mg}$ Polybrene, and $2.5 \mathrm{mg}$ soybean trypsin inhibitor. After separation of plasma, dilution with distilled water, and filtration through the lysine-Sepharose 4B column, the column was eluted at room temperature with $0.3 \mathrm{M}$ sodium phosphate buffer $(\mathrm{pH} 7.5)$ until the OD of the effluent measured at $280 \mathrm{~nm}$ was $<0.030$ in comparison to the buffer. The column was then eluted with a small additional volume of $0.1 \mathrm{M}$ phosphate buffer, moved to $4^{\circ} \mathrm{C}$, and plasminogen eluted with the same buffer containing $0.01-$ 0.2 M 6-aminohexanoic acid (Sigma Chemical Co., St. Louis, MO.). The effluent with maximal protein content was pooled and filtered through Sephadex G-150 equilibrated with 0.025 M Tris (Sigma Chemical Co., pH 7.5) in 0.15 M sodium chloride and $0.1 \mathrm{mM}$ EDTA. The early protein peak corresponding to $\cong$ mol wt 80,000 was pooled, concentrated by ultrafiltration against a PM-10 membrane, dialyzed against barbital-saline buffer, and stored at $-70^{\circ} \mathrm{C}$ in silicone-coated polyethylene vials. These plasminogen preparations contained 20-28 Committee on Thrombolytic Agents (CTA) units per milligram protein. Small amounts of plasmin were present in some preparations, as determined by functional assay; only those preparations containing no detectable plasmin were used for the experiments described.

For some experiments, plasminogen was treated with diisopropyl fluorophosphate (DFP, obtained as a $0.3 \mathrm{M}$ solution in isopropanol through the courtesy of Dr. J. Pensky, Cleveland Veterans Administration Hospital) to insure plasmin inactivation. At room temperature, the $0.3 \mathrm{M}$ DFP solution was added dropwise to the plasminogen solution in polystyrene tubes to a final concentration of $0.01 \mathrm{M}$. After incubation at room temperature for $2 \mathrm{~h}$, the DFP was removed by exhaustive dialysis at $4^{\circ} \mathrm{C}$ against barbital-saline buffer and the plasminogen was assayed without refreezing. This procedure totally inactivated plasmin formed by incubating streptokinase (Lederle Laboratories, Pearl River, N. Y.; reference standard streptokinase diluted in barbital-saline buffer) with plasminogen ( $5 \mathrm{U}$ streptokinase $/ \mu \mathrm{g}$ plasminogen) at $37^{\circ} \mathrm{C}$ for $30 \mathrm{~min}$.

Human fibrinogen (IMCO Corp Ltd, Stockholm, Sweden, $97.3 \pm 0.1 \%$ coagulable protein) was further purified to remove contaminating plasminogen by filtration over lysineSepharose 4B and then adjusted to a concentration of 4 $\mathrm{mg} / \mathrm{ml}$ in barbital-saline buffer.

Human thrombin, 1,000 NIH U/mg (Lee Scientific, Inc., St. Louis, Mo.), was dissolved in barbital-saline buffer before use.

Crude bovine fibrinogen was fibrinogen bovine fraction I (Nutritional Biochemicals Corp., Cleveland Ohio). Crude bovine thrombin was Thrombin Topical (Parke, Davis, \& Co., Detroit, Mich). It was dissolved in barbital-saline buffer before use.

The synthetic amide H-D-valyl-leucyl-lysine-p-nitroanilide -2 $\mathrm{HCl}$ (VLLN, Kabi Diagnostica, AB Kabi, Sweden) was used at concentrations of 3-0.6 $\mathrm{mM}$ in barbital-saline buffer for plasmin assay, and the synthetic amide PPAN at concentrations of $0.1 \mathrm{mM}$ in barbital-saline buffer for assay of plasma kallikrein.

Rabbit antiserums to human $\mathrm{HF}$ and human plasma kallikrein were prepared and treated as reported (15). Monospecific antiserums were prepared by absorption with specific factor-deficient plasmas and separation of a crude IGG fraction (15). Each monospecific antiserum formed a single line upon immunodiffusion through $0.9 \%$ agarose in barbitalsaline buffer against pooled normal plasma but no line against specific factor-deficient plasma.

Kaolin-activated euglobulin for assay of fibrinolytic activity in normal plasma was prepared as described (9).

Fibrin plates were Enzo-Diffusion Fibrin Plates (Hyland Laboratories, Costa Mesa, Calif.).

Barbital-Saline buffer was $0.025 \mathrm{M}$ barbital in $0.125 \mathrm{M}$ sodium chloride ( $\mathrm{pH} 7.5$ ).

Kaolin, Centrolex "O," alpha casein, and siliconized glassware and vials were obtained or prepared as described (13).

All tests, unless otherwise specified, were performed in Falcon polystyrene tubes (Falcon Plastics, Div. of BioQuest, Oxnard, Calif.).

All other chemicals employed were reagent grade.

Coagulation assays for $\mathrm{HF}$, plasma prekallikrein, HMWK, and other coagulation factors were performed by reported methods $(4,13,16,17)$ except that Centrolex $O$ was employed in place of Gliddex-P as a source of phospholipid.

Measures of plasmin included caseinolytic assays, clot lysis assays on a standardized fibrin clot, fibrin plate assays, and synthetic substrate (VLLN) assays. Caseinolytic assays were performed by a modification of the method of Remmert and Cohen (18) in which streptokinase (100 U/0.5 Remmert and Cohen unit plasminogen) was used to activate plasminogen. Clot lysis assays for plasmin employed both human and bovine fibrinogen and thrombin. In the bovine system, $0.1 \mathrm{ml}$ 
TABLE I

Activation of Plasminogen by Hageman Factor

\begin{tabular}{lc}
\hline \multicolumn{1}{c}{ Activator system $^{*}$} & \\
\hline & $\mu m o l ~ p N A / h \ddagger$ \\
$\mathrm{HF}+$ kaolin & $<1$ \\
$\mathrm{HF}+$ plasminogen & $<1$ \\
$\mathrm{Kaolin}+$ plasminogen & $<1$ \\
$\mathrm{HF}$ & $<1$ \\
$\mathrm{HF}+$ kaolin + plasminogen & $42-53 \S$ \\
$\mathrm{HF}_{\mathrm{f}}+$ plasminogen & $11-22 \$$ \\
\hline
\end{tabular}

* $\mathrm{HF}$ at $1 \mathrm{U} / \mathrm{ml}$, plasminogen at $1.0 \mathrm{CTA} \mathrm{U} / \mathrm{ml}, \mathrm{HF}_{\mathrm{f}}$ at protein equivalent of $\mathrm{HF}$, kaolin at $2-5 \mathrm{mg} / \mathrm{ml}$. Sample size $0.1 \mathrm{ml}$. Activator system incubated $30 \mathrm{~min}$ at $37^{\circ} \mathrm{C}$ before assay on VLLN.

‡ VLLN at final concentration $0.3 \mathrm{mM}, 1.0 \mathrm{ml}$ substrate added to system.

$\S$ Range of activity with varying combinations of four different $\mathbf{H F}$, two different $\mathbf{H F}_{\mathrm{f}}$ and three different plasminogen preparations. Duplicate assays varied by no $>10 \%$ at activities of $5-25 \mu \mathrm{mol} \mathrm{pNA} / \mathrm{h}$ and by no $>5 \%$ with activities $\geq 25 \mu \mathrm{mol} \mathrm{pNA} / \mathrm{h}$

of test sample, $0.2 \mathrm{ml}$ of fibrinogen $(4 \mathrm{mg}$ dry $\mathrm{w} / \mathrm{ml}$ of barbital-saline buffer) and $0.1 \mathrm{ml}$ of thrombin, (20 National Institutes of Health $\mathrm{U} / \mathrm{ml}$ of barbital-saline buffer) were added to $10 \times 75 \mathrm{~mm}$ polystyrene tubes, mixed, and incubated at $37^{\circ} \mathrm{C}$. The lysis time recorded was the time elapsing until the disappearance of bubbles from the clot. In the human test system, a similar procedure was used but employed 0.2 $\mathrm{ml}$ of the fibrinogen solution diluted with an equal volume of the same buffer and $0.1 \mathrm{ml}$ of thrombin (10 NIH $\mathrm{U} / \mathrm{ml}$ of barbital-saline buffer). In these systems, the clot lysis times of redissolved kaolin-activated euglobulin derived from $0.1 \mathrm{ml}$ of normal pooled plasma were $6.5-8.5 \mathrm{~min}$. To assay streptokinase-activated plasminogen by clot lysis, $0.1 \mathrm{ml}$ of the test sample, $0.2 \mathrm{ml}$ of bovine fibrinogen $(4 \mathrm{mg} / \mathrm{ml}), 0.1 \mathrm{ml}$ of thrombin $(20 \mathrm{NIH} \mathrm{U} / \mathrm{ml})$, and $0.1 \mathrm{ml}$ of streptokinase $(1,000$ $\mathrm{U} / \mathrm{ml}$ of barbital-saline buffer) were added in rapid succession to polystyrene tubes $(10 \times 75 \mathrm{~mm}$.). After mixing, lysis at $37^{\circ} \mathrm{C}$ was recorded, using the same end point described above. In this assay, the clot lysis time of $0.1 \mathrm{ml}$ of a $1 / 30$ dilution of normal plasma in barbital-saline buffer was 260$290 \mathrm{~s}$. The clot lysis time of streptokinase-activated plasminogen $(0.002$ CTA units in $0.1 \mathrm{ml}$ of $1 \%$ bovine serum albumin in barbital-saline buffer) was $20 \mathrm{~min}$. In the absence of plasminogen, the clot lysis time exceeded $120 \mathrm{~min}$. The fibrin plate assay for plasmin activity was performed by incubating $\mathrm{HF}$ $(1.0 \mathrm{U} / \mathrm{ml})$ and plasminogen $(1.0 \mathrm{CTA} \mathrm{U} / \mathrm{ml})$ with the substance to be tested at $37^{\circ} \mathrm{C}$ for $30 \mathrm{~min}$ in polystyrene tubes. $\mathbf{H F}_{\mathrm{f}}$ were tested at the same protein concentration as $\mathrm{HF}$. 10- $\mu$ l samples were placed in the plate wells and the zones of lysis were recorded after $4 \mathrm{~h}$ at $37^{\circ} \mathrm{C}$. The area of lysis around the well (not including the well itself) was compared to the area around wells containing $10 \mu \mathrm{l}$ of kaolin-activated euglobulin.

VLLN assays of plasmin activity were performed at substrate concentrations of 3 to $0.6 \mathrm{mM}$ in barbital-saline buffer. The sample to be tested (usually $0.1 \mathrm{ml}$ ) was incubated with $1.0 \mathrm{ml}$ of substrate for variable time intervals (usually 10-30 min) at $37^{\circ} \mathrm{C}$ in polystyrene tubes and the reaction stopped by addition of $1 / 10 \mathrm{vol}$ of glacial acetic acid. The OD at 405 $\mathrm{nm}$ was read against a blank in which the acid was added before the substrate. Under these conditions, a linear curve of amidolytic activity was observed when the test sample contained 0.0025-0.04 CTA units of streptokinase-activated plasminogen. Assays were performed within this range and results recorded as micromoles of $p$-nitroaniline (pNA) per hour, as determined by comparison with pNA in the same buffer. Duplicate samples over this range varied no $>10 \%$ at low levels of plasmin activity (0.0025-0.01 U) and by no $>5 \%$ with greater plasmin activities.

PPAN assay for plasmin kallikrein activity or plasma prekallikrein activation were performed in a fashion similar to the VLLN assay. The test sample, usually $0.1 \mathrm{ml}$, was incubated in polystyrene tubes with $1.0 \mathrm{ml}$ of $0.1 \mathrm{mM}$ PPAN, usually for 10-20 min, the reaction was stopped by addition of $1 / 10 \mathrm{vol}$ of glacial acetic acid, and OD at $405 \mathrm{~nm}$ was read against a blank in which acid was added before substrate. Assays were performed within a range giving linear results with dilutions of purified plasma kallikrein.

Radioimmunoassay for PTA was performed by a double antibody technique sensitive to $0.003 \mathrm{U} P T A / \mathrm{ml}$ in a $0.1-\mathrm{ml}$ sample volume, $1 \mathrm{U}$ being the amount in $1 \mathrm{ml}$ of pooled normal plasma (19).

Protein was determined by the method of Lowry et al. (20).

Dialysis were performed at $4^{\circ} \mathrm{C}$ in cellophane casings as described (13).

Centrifugations were performed at $2^{\circ} \mathrm{C}$ in an International PR-2 refrigerated centrifuge (International Equipment Co., Needham Heights, Mass.) and at high speeds in a Servall RC-2 refrigerated centrifuge (Ivan Sorvall, Inc., Norwalk, Conn.) (13).

\section{RESULTS}

Activation of plasminogen by Hageman factor. When HF, kaolin, and plasminogen were incubated together, significant amounts of amidolytic activity for the synthetic substrate VLLN were consistently observed (Table I). Evolution of this activity required the presence of all three agents in the incubation mixture. Similar activity, but at a consistently lower level, was noted when $\mathrm{HF}_{\mathrm{f}}$ were incubated with plasminogen in the absence of kaolin.

Incubation of physiologic concentration of $\mathrm{HF}$ and plasminogen, in the presence of kaolin, led to progressively higher levels of amidolytic activity for incubations up to $60 \mathrm{~min}$ (Fig. 1). A similar pattern of amidolytic activity was seen with lower concentrations of plasminogen but the maximum levels of activity were correspondingly less. The initial rate of development of amidolytic activity was slightly less than linearly related to $\mathrm{HF}$ concentration (Fig. $2 \mathrm{~A}$ ). In contrast, increased concentrations of plasminogen resulted in no additional increment of initial rate of rise in amidolysis for molar ratios of plasminogen: $\mathrm{HF}$ of $\geq 50$ (Fig. $2 B$ ). Once maximal amidolytic activity was achieved with physiologic concentrations of $\mathrm{HF}$ and plasminogen, subsequent addition of $\mathrm{HF}$ did not yield significant additional activity (Fig. 3). In contrast, addition of equivilent quantities of plasminogen increased the yield of amidolytic activity. These data suggest an enzymatic role for Hageman factor, in the presence of kaolin, acting upon plasminogen as a substrate. 


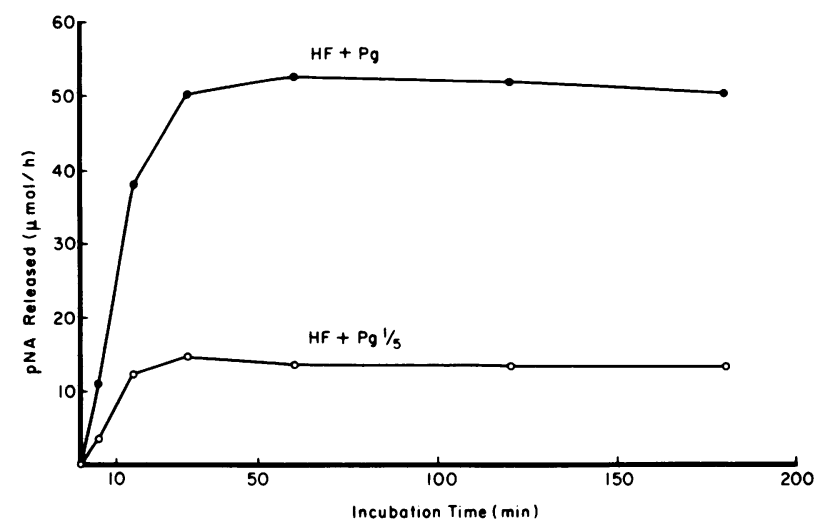

FIGURE 1 Kaolin-activated formation of plasmin. HF $(0.25$ or $1.0 \mathrm{U} / \mathrm{ml})$ and plasminogen $(\mathrm{Pg})(1.0$ or $0.2 \mathrm{CTA} \mathrm{U} / \mathrm{ml})$ were incubated with kaolin $(2.0 \mathrm{mg} / \mathrm{ml})$ for the designated time intervals at $37^{\circ} \mathrm{C}$. Polybrene $(100 \mu \mathrm{g} / \mathrm{ml}$ final concentration) was then added and plasmin activity against the VLLN substrate was measured as micromoles pNA per hour (see Methods).

The rate of rise of amidolytic activity with increasing HF concentration was not strictly linear. This might reflect trace contamination of the HF preparation with an inhibitor or, alternatively, product inhibition of $\mathrm{HF}$ activity; because plasmin is known to attack HF (21) and as a product of this interaction, $\mathrm{HF}_{\mathrm{f}}$, is less effective than equimolar amounts of $\mathrm{HF}$ in plasminogen activation (Table I), the latter possibility seems probable. The curve is the inverse of that expected with contamination of the HF preparation by a cofactor or enzymic activator.

Inhibition studies and assays for contaminants. Because plasma kallikrein hydrolyzes VLLN and because an unidentified contaminant might have been
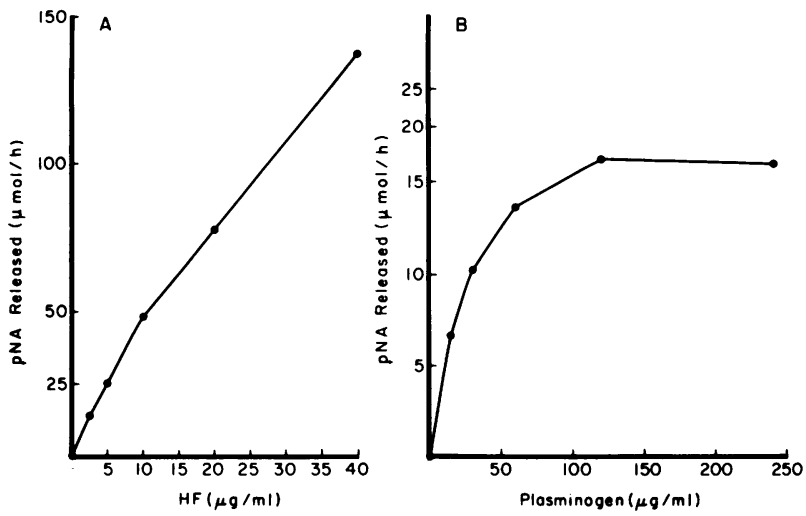

FIGURE 2 Effect of varying Hageman factor and plasminogen concentrations on initial reaction velocities. HF (A) or plasminogen (B) were incubated at varying concentrations with plasminogen $(120 \mu \mathrm{g} / \mathrm{ml})$ or $\mathrm{HF}(2.5 \mu \mathrm{g} / \mathrm{ml})$, respectively, for $15 \mathrm{~min}$ at $37^{\circ} \mathrm{C}$. Polybrene $(100 \mu \mathrm{g} / \mathrm{ml}$ final concentration) was added and plasmin activity against the VLLN substrate was measured (see Methods).

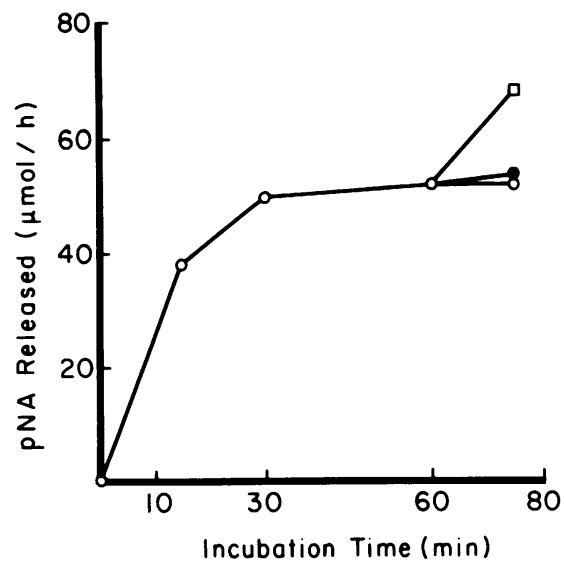

Figure 3 Effect of added plasminogen or Hageman factor upon plasmin activity. After incubation of $\mathrm{HF}$ (1.0 $\mathrm{U} / \mathrm{ml}$ ) and plasminogen $\left(1.0 \mathrm{CTA} \mathrm{U} / \mathrm{ml}\right.$ ) for $60 \mathrm{~min}$ at $37^{\circ} \mathrm{C}$, additional plasminogen $(\square), \mathrm{HF}(\bullet)$, or bovine serum albumin (O) $2.5 \mu \mathrm{g}$ in $0.02 \mathrm{ml}$ was added and the mixture further incubated for $15 \mathrm{~min}$. Polybrene ( $100 \mu \mathrm{g} / \mathrm{ml}$ final concentration) was then added and VLLN activity was measured (see Methods).

present in preparations of $\mathrm{HF}$, inhibition studies with monospecific antiserum and Polybrene, a cationic inhibitor of HF function, were performed (Table II). The IgG fraction of rabbit antiserum directed against human plasma kallikrein, in amounts capable of neutralizing four times the quantity of plasma kallikrein that would generate the same amount of activity against the VLLN substrate, showed no effect upon the interaction of $\mathrm{HF}$, kaolin, and plasminogen whether it was provided before or after incubation of $\mathrm{HF}$ with kaolin. In contrast, anti-HF antiserum almost totally inhibited amidolysis. The addition of Polybrene either before or after incubation of HF with kaolin totally inhibited amidolysis but had no effect on amidolysis after $\mathrm{HF}$, kaolin, and plasminogen had been incubated together. These observations suggest that HF itself, rather than some unidentified product of the interaction of $\mathrm{HF}$ and kaolin, was essential to the generation of amidolysis.

Additional studies designed to detect contamination of the HF and plasminogen preparations with agents that might produce the observed results were performed. PTA in its activated form demonstrates activity against the VLLN substrate ${ }^{2}$ and has recently been implicated as a proactivator in HF-mediated fibrinolysis (11). The individual preparations did not differ significantly in clotting factor activity from that of buffer alone $(\leq 0.005 \mathrm{U} / \mathrm{ml})$ and no PTA was detected by radioimmunoassay (18) sensitive to $0.003 \mathrm{U} / \mathrm{ml}$ PTA in a $0.1-\mathrm{ml}$ sample.

Coagulation assays for HMWK in the individual

\footnotetext{
${ }^{2}$ Ratnoff, O. D. Unpublished observation.
} 
TABLE II

Inhibition of the Activation of Plasminogen

by Hageman Factor

\begin{tabular}{|c|c|c|c|}
\hline $\begin{array}{l}\text { Incubation } \\
\text { mixture* }\end{array}$ & plus First addition* plus & s Second addition* & Amidolysis \\
\hline & & & $\mu \mathrm{mol} p N A / h$ \\
\hline HF $\ddagger+$ buffer $\S$ & kaolin** & plasminogen $\rrbracket$ & 36 \\
\hline $\mathrm{HF}+$ rabbit IgG" & kaolin & plasminogen & 39 \\
\hline $\mathbf{H F}+$ anti-HF" & kaolin & plasminogen & 3 \\
\hline HF + Polybrene" & kaolin & plasminogen & $<1$ \\
\hline \multicolumn{4}{|l|}{ HF + anti- } \\
\hline kallikrein" & kaolin & plasminogen & 36 \\
\hline $\mathrm{HF}+$ kaolin & buffer or IgG & plasminogen & 39 \\
\hline $\mathrm{HF}+$ kaolin & antikallikrein & plasminogen & 43 \\
\hline HF + kaolin & Polybrene & plasminogen & $<1$ \\
\hline $\mathrm{HF}+$ kaolin & plasminogen & Polybrene & 65 \\
\hline
\end{tabular}

* All incubations at $37^{\circ} \mathrm{C}$ for $30 \mathrm{~min}$. Final volume of test system $0.2 \mathrm{ml}$.

$\ddagger \mathrm{HF}$ at $0.75 \mathrm{U} / \mathrm{ml}$.

\$ Buffer (barbital-saline), $100 \mu \mathrm{l}$.

"Rabbit IgG or antiserum at $15 \mathrm{mg} / \mathrm{ml}$ barbital-saline, $100 \mu \mathrm{l}$.

If Polybrene $50 \mu \mathrm{g} / \mathrm{ml}$ final concentration.

** Kaolin $3 \mathrm{mg} / \mathrm{ml}$, final concentration.

\$ Plasminogen $0.8 \mathrm{CTA} \mathrm{U} / \mathrm{ml}$.

preparations similarly showed no difference from the effects of buffer alone. An incubated mixture of HF, kaolin, and plasminogen shortened the coagulation time of Fitzgerald trait (HMWK-deficient) plasma from $>300 \mathrm{~s}$ to $250-270 \mathrm{~s}$, in agreement with earlier studies in which partial correction by plasmin of the coagulation defect of HMWK-deficient plasma was noted (22).

In addition to the experiments in Table II, prekallikrein or kallikrein was not detected by assay of the protein preparations individually or together upon the plasma kallikrein substrate PPAN. Small amounts of amidolytic activity against this substrate were generated by an incubated mixture of $\mathrm{HF}$, kaolin, and plasminogen, but similar activity was produced by streptokinase-activated plasminogen. Monospecific rabbit antiplasma kallikrein antiserum did not inhibit such amidolysis but did block amidolysis of this substrate by plasma kallikrein and by plasma prekallikrein that had been activated by $\mathrm{HF}$ and kaolin or by $\mathrm{HF}_{\mathrm{f}}$.

The possibility that small amounts of plasmin contaminated the plasminogen preparations, thus influencing the hydrolysis of VLLN, was examined because this enzyme may convert $\mathrm{HF}$ to an enzymatically active form (21). No plasmin was detected in the plasminogen or HF preparations employed, as measured by casinolysis, amidolysis of VLLN, or bovine clot lysis assays capable of detecting 0.0002 CTA units human plasmin in $0.1 \mathrm{ml}$. Additionally, exposure of the plasminogen preparations to DFP under conditions that caused total inactivation of streptokinase-activated plasminogen did not inhibit the activity of HF and kaolin upon the plasminogen once DFP had been removed by dialysis.
Correlation of amidolytic activity with clot and fibrin plate lysis. Amidolytic activity against the VLLN substrate by the HF-kaolin-plasminogen mixture was compared to standardized clot lysis and fibrin plate lysis induced by the same mixture (Table III). In the presence of kaolin, a mixture of HF, and plasminogen, in amounts equivalent to those present in the resuspended kaolin-activated euglobulin fraction of normal plasma, consistently shortened the clot lysis time of human or bovine clots in comparison to buffer or in comparison to a mixture of the two protein fractions in the absence of kaolin. The degree of shortening observed, however, did not lie within the linear portion of the curve derived by plotting clot lysis time against serial dilutions of normal kaolinactivated euglobulin. Thus, a reliable comparison of plasminogen activation relative to kaolin-activated euglobulin could not be made.

When plasmin activation was measured on a commercial fibrin plate, said to be plasminogen-free, small amounts of plasmin activity were generated by the mixture of kaolin, HF, and plasminogen, as compared with a comparable quantity of kaolin-activated euglobulin. Comparison of plasminogen activation by the purified system with plasma euglobulin was obscured by the finding that the commercial plates were contaminated with small amounts of plasminogen; purified streptokinase alone formed annular rings of lysis at a distance from the central well proportional to the concentration of streptokinase.

Substitution of equivalent protein quantities of $\mathrm{HF}_{\mathrm{f}}$ for $\mathrm{HF}$ resulted in an erratic range of clot lysis times

TABLE III

Correlation with Clot Lysis and Fibrin Plate

\begin{tabular}{lcccc}
\hline & & \multicolumn{3}{c}{ Clot lysis } \\
\cline { 3 - 5 } \multicolumn{1}{c}{ Activator system* } & & Bovine & Human & $\begin{array}{r}\text { Fibrin } \\
\text { plate }\end{array}$ \\
\hline & $\mu$ mol pNA* & $\min$ & $\min$ \\
Buffer & $<1$ & $>120$ & $>120$ & 0.00 \\
HF + plasminogen & $<1$ & $>120$ & $>120$ & 0.00 \\
HF + kaolin & $<1$ & $>120$ & $>120$ & 0.00 \\
$\begin{array}{l}\text { HF + kaolin + plas- } \\
\text { minogen. }\end{array}$ & 45 & 27 & 32 & 0.15 \\
$\begin{array}{l}\text { Plasma kaolin- } \\
\quad \begin{array}{l}\text { activated } \\
\text { euglobulin }\end{array}\end{array}$ & & & & \\
HF + plasminogen & $14-16$ & $67-83$ & $64-88$ & 0.00 \\
\hline
\end{tabular}

${ }^{*} \mathrm{HF}, \mathrm{HF}_{\mathrm{f}}$, activator system, and VLLN results as in Table I. Plasma euglobulin as in Methods, incubated for $60 \mathrm{~min}$ in the presence of kaolin.

$\ddagger$ Expressed as ratio of area lysed to area lysed by plasma kaolin-activated euglobulin containing equivalent quantities of $\mathrm{HF}$ and plasminogen. 
that were consistently shorter than buffer times but longer than the times observed with $\mathrm{HF}$ and plasminogen in the presence of kaolin. $\mathrm{HF}_{\mathrm{f}}$ induced no detectable activity in the fibrin plate system. These results, coupled with the lower levels of amidolytic activity against VLLN formed by $\mathrm{HF}_{\mathrm{f}}$ and plasminogen, suggest that the level of plasmin activation achieved with $\mathrm{HF}_{\mathrm{f}}$ was below the threshold of detection by the fibrin plate technique.

\section{DISCUSSION}

The data presented here offer evidence for a direct enzymatic attack of purified human HF upon purified human plasminogen in the presence of a negatively charged surface as measured by activity upon a synthetic plasmin substrate, VLLN. This activity displayed kinetic characteristics of enzymatic action of $\mathrm{HF}$ preparations upon plasminogen. Plasmin activity generated under these conditions was also measured by clot lysis and fibrin plate lysis, techniques commonly employed by other investigators. Activity in these systems was detectable, but it was outside of the range of reliable quantitative assay.

The preparations used in these experiments were free of detectable contamination by plasma prekallikrein, kallikrein, or HMWK, protein species previously implicated in this system. In addition, inhibition studies employing monospecific rabbit antiserum directed against human plasma kallikrein showed that plasminogen activation under these conditions was not dependent on this enzyme.

Specific antiserums or inhibition assays were not available to test directly for the reported HF-cofactor (9), the plasminogen proactivator isolated from plasma prekallikrein (10), or the recently described proactivator isolated in association with PTA (11). Indirect evidence points against contamination with these species as responsible for the observed results. The molecular weights of the protein preparations used, both of which were subjected to gel filtration during purification, differed significantly from that of HF-cofactor or the recently described PTA-associated plasminogen proactivator. In addition, the behavior on anion exchange gradient chromatography of the two plasminogen proactivator species described earlier differs markedly from that of the HF preparations we used, eluting at much lower ionic strengths. Furthermore, no contamination of our protein preparations with prekallikrein or PTA was found upon direct assay by several techniques. Finally, inhibition of plasmin activation by hexadimethrine bromide was equally effective before and after incubation of $\mathrm{HF}$ with kaolin, indicating the necessity for $\mathrm{HF}$ itself, rather than some undetected agent generated by the interaction of $\mathrm{HF}$ with a negatively charged surface. The plasminogen used was prepared by techniques comparable to those in which a proactivator was demonstrated (10) and had a specific activity comparable to highly purified preparations used by other investigators (23).

Previous studies that failed to demonstrate an effect of purified HF upon plasminogen employed systems in which either the plasminogen source $(24)$ or both the $\mathrm{HF}$ and plasminogen source (25), were bovine. In our bovine clot lysis system, a HF-kaolin mixture also showed no fibrinolytic activity upon exposure to a bovine plasminogen-rich fibrin clot. Other agents such as streptokinase also demonstrate such specificity for the human plasminogen substrate.

The necessity of HF-cofactor for generation of plasma fibrinolytic activity was demonstrated in a complex system differing from our purified protein preparations in several ways (9). A glass-adsorbed plasma substrate devoid of prekallikrein and probably largely devoid of HMWK was assayed as a euglobulin fraction that has been found to contain significant inhibitory activity against $\mathrm{HF}$, attributed to the presence of CI inactivator (26).

Our results are in accord with most published data using fibrin plate and clot lysis techniques to measure plasmin activation in that no consistent activity was demonstrable by these methods when small molecular weight $\mathrm{HF}_{\mathrm{f}}$, used by other investigators $(10,27)$, was employed as the source of $\mathrm{HF}$.

Although these data indicate that HF may directly activate plasminogen to plasmin, the level of plasmin activity obtained by this interaction appears to be quantitatively less than that obtained by the intrinsic surface-activated pathway of fibrinolysis in normal whole plasma. Experiments with factor-deficient plasmas have shown that some role is played by plasma prekallikrein or kallikrein and HMWK, and possibly other agents. The extent to which these other species act in an enzymatic fashion, or perhaps protect the HFplasminogen interaction from plasma protease inhibitors, remains to be clarified.

\section{ACKNOWLEDGMENTS}

We wish to thank Dr. K. Neet, Department of Biochemistry, Case Western Reserve University, for his helpful discussion of enzyme kinetics.

This work was supported in part by research grant HL 01661 from the National Heart, Lung, and Blood Institute, the National Institutes of Health, U. S. Public Health Service, and in part by grants from the American Heart Association and its Northeast Ohio Affiliate.

\section{REFERENCES}

1. Plow, E. F., and T. S. Edgington. 1975. An alternative pathway for fibrinolysis. I. Cleavage of fibrinogen by leucocyte proteases at physiologic $\mathrm{pH}$. J. Clin. Invest. 56: $30-38$. 
2. Niewiarowski, S., and O. Prou-Wartelle. 1959. Role de facteur contact (facteur Hageman) dans la fibrinolyse. Thromb. Diath. Haemorrh. 3: 593-598.

3. Iatridis, S. G., and J. H. Ferguson. 1961. Effect of surface and Hageman factor on the endogenous or spontaneous activation of the fibrinolytic system. Thromb. Diath. Haemorrh. 6: 411-422.

4. Saito, H., O. D. Ratnoff, and V. H. Donaldson. 1974. Defective activation of clothing, fibrinolytic, and permeability-enhancing systems in human Fletcher trait plasma. Circ. Res. 34: 641-651.

5. Wuepper, K. D. (1972). Biochemistry and biology of components of the plasma kinin-forming system. In Inflammation: Mechanism and Control, I. H. Lepow and P. A. Ward, editors., Academic Press, Inc., New York. 93-117.

6. Weiss, A. S., J. I. Gallin, and A. P. Kaplan. 1974. Fletcher factor deficiency: a diminished rate of Hageman factor activation caused by absence of prekallikrein with abnormalities of coagulation, fibrinolysis, chemotactic activity and kinin generation. J. Clin. Invest. 53: 622-633.

7. Saito, H., O. D. Ratnoff, R. Waldmann, and J. P. Abraham. 1975. Fitzgerald trait. Deficiency of a hitherto unrecognized agent, Fitzgerald factor, participating in surface-mediated reactions of clotting, fibrinolysis, generation of kinins, and the property of dilated plasma enhancing vascular permeability (PF/DIL). J. Clin. Invest. 55: 1082-1089.

8. Colman, R. W. 1969. Activation of plasminogen by human plasma kallikrein. Biochem. Biophys. Res. Commun. 35: 273-279.

9. Ogston, D., M. Ogston, O. D. Ratnoff, and C. B. Forbes. 1969. Studies on a complex mechanism for the activation of plasminogen by kaolin and chloroform: the participation of Hageman factor and additional cofactors. J. Clin. Invest. 48: 1786-1801.

10. Kaplan, A. P., and K. F. Austen. 1972. The fibrinolytic pathway of human plasma. Isolation and characterization of the plasminogen proactivator. J. Exp. Med. 136: 1378-1393.

11. Mandle, R., Jr., and A. P. Kaplan. 1977. Plasminogen proactivators of human plasma: relationship to prekallikrein and Factor XI. Fed. Proc. 36: 329. (Abstr.)

12. Kaplan, A. P., H. L. Meier, and R. Mandle, Jr. 1969. The Hageman factor dependent pathways of coagulation, fibrinolysis, and kinin-generation. Semin. Thromb. Hemostasis. 3: 1-26.

13. Saito, H., O. D. Ratnoff, J. S. Marshall, and J. Pensky. 1973. Partial purification of plasma thromboplastin antecedent (Factor XI) and its activation by trypsin. J. Clin. Invest. 52: 850-861.
14. Deutsch, D. G., and E. T. Mertz. 1970. Plasminogen: purification from plasma by affinity chromatography. Science (Wash. D. C.). 170: 1095-1096.

15. Ratnoff, O. D. 1972. Studies on the product of the reaction between activated Hageman factor (Factor XII) and plasma thromboplastin antecedent (Factor XI). J. Lab. Clin. Med. 80: 704-710.

16. Forbes, C. D., and O. D. Ratnoff. 1972. Studies on plasma thromboplastin antecedent (Factor XI), PTA deficiency and inhibition of PTA by plasma, pharmacologic inhibitors and specific antiserum. J. Lab. Clin. Med. 79: 113-127.

17. Saito, H., G. Goldsmith, and R. Waldmann. 1976. Fitzgerald factor (high molecular weight kininogen) clotting activity in human plasma in health and disease and in various animal plasmas. Blood. 48: 941-947.

18. Kline, D. L. 1971. Caseinolytic techniques. In Thrombosis and Bleeding Disorders, N. U. Bang, F. K. Beller, E. Deutsch, E. F. Mammon, editors. Academic Press, Inc., New York. 358-360.

19. Saito, H., and G. Goldsmith. 1977. Plasma thromboplastin antecedent (Factor $\mathrm{XI}$ ): a specific and sensitive radioimmunoassay. Blood. 50: 377-385.

20. Lowry, O. H., N. J. Rosebrough, A. L. Farr, and R. J. Randall. 1951. Protein measurement with the Folin phenol reagent. J. Biol. Chem. 193: 265-268.

21. Revak, S. D., C. G. Cochrane, A. R. Johnson, and T. E. Hugli. 1974. Structural changes accompanying enzymatic activation of human Hageman factor. J. Clin. Invest. 54: 619-627.

22. Kaplan, A. P., A. Bagdasarian, and R. W. Colman. 1975. Williams trait deficiency. Abnormalities of coagulation, fibrinolysis, and kinin generation and their relationship to plasminogen practivator. Clin. Res. 23: 403A. (Abstr.)

23. Robbins, K. C., and L. Summaria. 1976. Plasminogen and plasmin. Methods. Enzymol. 45: 259-262.

24. Ratnoff, O. D., and E. W. Davie. 1962. The purification of activated Hageman factor (activated Factor XII). Biochemistry. 1: 967-975.

25. Schoenmakers, J. G. G., R. M. Kurstjens, C. Haanen, and F. Zilliken. 1963. Purification of activated bovine Hageman factor. Thromb. Diath. Haemorrh. 9: 546-556.

26. Kluft, C. 1976. Occurrence of $\mathrm{Cl}$ inactivator and other protein inhibitors in euglobulin fractions and their influence on fibrinolytic activity. Haemostasis. 5: 136-146.

27. Laake, K., and A. M. Vennerod. 1974. Factor XIIinduced fibrinolysis: studies on the separation of prekallikrein, plasminogen proactivator, and factor XI in human plasma. Thromb. Res. 4: 285-302. 